\title{
OPINION
}

\section{Disease resistance in plants: The road to phytoalexins and beyond}

\author{
Tamas Komives ${ }^{1,2}$ and Zoltan Kiraly ${ }^{1}$ \\ ${ }^{1}$ Plant Protection Institute, Centre for Agricultural Research, Hungarian Academy of Sciences, Herman Otto 15, 1022 Budapest, Hungary, \\ ${ }^{2}$ Institute of Agricultural Sciences and Environmental Management, Eszterhazy Karoly University, Matrai ut 36, 3200 Gyongyos, Hungary
}

E-mail addresses: komives.tamas@agrar.mta.hu and kiraly.zoltan@agrar.mta.hu

\begin{abstract}
This paper summarizes the views of the authors on the roles of specific metabolites play in the resistance of plants against bacterial and fungal diseases. Antimicrobial specific plant metabolites may be synthesized in plant tissues constitutively (phytoanticipins) or in response to microbial infections (phytoalexins). This paper identifies certain key steps in the discovery of phytoalexins and touches upon the current state of phytoalexin research.
\end{abstract}

Keywords - phytoalexins, toxins, specific metabolites, plant disease resistance, pathogens, bacteria, fungi

What is food to one man is bitter poison to others. Lucretius Carus, ca. 50 BC (Carus, 1886)

\section{INTRODUCTION}

Plants as sessile organisms are constantly exposed to adverse and/or beneficial environmental factors, both biotic (symbionts, pathogens, herbivores, pollinators, competing plants, etc.) and abiotic (excess/deficiency of nutrients, water, salinity, and light, as well as high/low temperature, xenobiotics, etc.) factors.

Based on their infection strategies plant pathogenic microorganisms are classified as necrotrophs, biotrophs, and hemibiotrophs (Petriacq et al., 2016). Necrotrophic pathogens need to kill the host cells in order to use the decayed plant material as a substrate. In contrast, biotrophic pathogens parasitize living plant tissues by using effectors (in a broader sense, small molecules and macromolecules such as proteins) that paralyze and reprogram the host's immune system (Hogenhout et al., 2009) and may manipulate its microbiome (Snelders et al., 2018). The majority of plant pathogenic microorganisms utilize a hemibiotrophic infection strategy: this consists of an initial biotrophic phase, which, at a later stage, is followed by a necrotrophic infection. Resistance to necrotrophic pathogens is nonspecific, that is, effective against practically all pathogenic races. Resistance to biotrophic pathogens is specific because only one or a few plant cultivars exhibit resistance to one or a few pathogenic races (cf. Kiraly et al., 2013).

The ability of plants to respond to these factors by modifying the flow of their metabolism made them capable to colonize some extremely hostile terrains. In this paper, we will focus on certain antimicrobial specific metabolites that represent a small segment of the chemical means that are vastly important for the survival of plants. These metabolites are small molecules that are produced by plant tissues constitutively or in response to microbial infection. They are structurally highly diverse (depending on the taxa, species, tissue, developmental stage, etc.) (Komives and Casida, 1983; Jeandet, 2015; Jeandet, 2017), but basically they belong to one of the three categories of the so-called specific metabolites plants synthesize (Komives, 2017): alkaloids, phenylpropanoids, and terpenoids ${ }^{1}$. We will also discuss the key steps leading to the discovery of phytoalexins and the

\footnotetext{
${ }^{1}$ Constitutively synthesized specific, antimicrobial metabolites (called phytoanticipins, Reiter et al., 2017) are not subject of this paper.
} 
roles these specific metabolites play in the resistance of plants against bacterial and fungal diseases.

\section{MILESTONES}

\section{First observations of resistance of plants against pests and diseases}

The ability of plants to resist colonizing insects was observed as early as 1792 in the United States: the 'Underhill' wheat variety was reported to be resistant to the newly introduced pest Hessian fly (Mayetiola destructor) (Havens, 1792).

In comparison, the first report on plant resistance against diseases was published more than a century later by Marshall H. Ward (1902). Ward noticed that attempts to colonize resistant Bromus spp. plants with Puccinia dispersa fungus led to necrosis of the plant cells closest to the infection site. Based on his studies he proposed the breeding of disease-resistant plants. The immediate death of plant cells surrounding the infection zone in resistant plants was later termed hypersensitive response (HR) by Elvin C. Stakman (1915). During the following decades, disease resistance of plants became an intensively investigated field: a great number of papers and books were published on the subject (for a recent review see Silva et al. 2018). Unfortunately, most of this research focused on HR as was emphasized by Kiraly et al. (1972), who expressed that HR is the consequence and not the cause of plant disease resistance. Similarly, Szatmari et al. (2016) emphasized that alternative, and possibly more important mechanisms of resistance, e.g. basal resistance (also called innate immunity and nonspecific resistance) should be paid more attention.

\section{The toxin hypothesis in plant pathology}

Augustine P. de Candolle was the first to recognize the importance of potentially toxic chemicals in plant-herbivore (Candolle, 1804) and plant-plant (Candolle et al., 1832) interactions. Later, primarily theoretical considerations by Otto Kuntze (1877) and Wilhelm O. Focke (1881) extended this concept to consider the ability of plant exudates to protect plants against fungal infection.

Anton de Bary (1884) suggested that microorganisms may produce toxins (not only small molecules but also enzymes), that are capable of diffusing through the cuticles of plant organs and cause disease symptoms.

De Bary's toxin hypothesis was supported by observations of Ward et al. (1905), who explained the infection as well as the disease resistance of a plant the following way: "...infection, and resistance to infection, depend on the power of the Fungus-protoplasm to overcome the resistance of the cells of the host by means of enzymes or toxins; and, reciprocally, on that of the protoplasm of the cells of the host to form anti-bodies which destroy such enzymes or toxins, or to excrete chemotactic substances which repel or attract the Fungus-protoplasm". Decades later, the prominent Swiss botanist and mycologist Ernst A. Gaumann (1954) gave vigorous support for the toxin hypothesis and even claimed: "microorganisms are pathogenic only if they are toxigenic". Since Gaumann included plant growth regulating natural compounds as well as enzymes in his definition, the very broad statement was considered scientifically sound at that time.

Phytotoxins can be divided into host specific (selective) and nonspecific (nonselective) toxins, which means that a hostspecific toxin has the same host plant range than its toxinproducing pathogen.

It is interesting to note that, depending on the nature of the plant-pathogen interaction, toxins may influence plant metabolic processes in a variety of ways. For example, a toxin of a necrotrophic microorganism (e.g. victorin of Cochliobolus victoriae) may initiate plant cell death in the host. On the other hand, localized programmed cell death in plant tissues attacked by biotrophic or hemibiotrophic pathogens is a defense mechanism. Therefore, biotrophic pathogens do not produce toxins since phytotoxins are favorable only for necrotrophs and hemibiotrophs. It is noteworthy that the phytotoxin coronatine, produced by Pseudomonas syringae, can promote the infection by suppressing the salicylic acid-dependent defense (Geng et al., 2014). These examples illustrate the highly complex roles toxins may play in plant-pathogen interactions.

\section{Plant phenolics}

The first attempt to give a theoretical explanation for the disease resistance of plants was published by Ward et al. in 1905: he suggested that the presence of certain enzymes or toxins (or both) in the cells of the fungus, and of antitoxins (or similar substances) in the host cell may be responsible for the phenomenon. Experimental evidence for the involvement of specific, toxic metabolites of plants in plantmicrobe interactions was discovered by pioneering research in the laboratories of Melville T. Cook (Cook et al., 1911; Cook and Wilson, 1915) and Noel Bernard (1911). Cook and his coworkers found that tannin (a polyphenolic natural compound) inhibited the germination of the spores of a number of fungi, and ultimately the spores were killed. They also claimed that tannin is produced in the host plant upon injury to the cells by the action of the enzyme polyphenol oxidase (PPO) on some phenolic compounds and this reaction would produce a "germicidal fluid" that results in resistance of the host to parasitic attack (Cook et al., 1911). In the same year in a late note published by his wife after his death, Noel Bernard (1911) reported on the fungicidal capacity of orchids: "Mais j'avais gardé des racines, et, en les réexaminant, j'ai constaté qu'une de ces racines sur une douzaine était infestée. Il suffit donc d'une infestation relativement minime de la plante pour que les bulbes aient leur pouvoir fongicide" ${ }^{2}$. Bernard's observations (1) gave the first experimental evidence of the phenomenon known today

2 "...even a relatively limited infection of the plant (say one root out of twelve on Himantoglossum hircinum) is sufficient for the orchid's tubers to acquire fungicidal capacity." Translation from Selosse et al. (2011). 
as 'systemic acquired plant disease resistance' (re-discovered half a century later by Ross in 1961), and also (2) opened the road to the later identification of several antifungal specific metabolites produced by orchids (Selosse et al., 2011).

Two decades later, Albert Szent-Gyorgyi (winner of Nobel Prize for the discovery of vitamin $\mathrm{C}$ and biological oxidation) and Kalman Vietorisz (1931) hypothesized that the oxidation of polyphenols at the surface of freshly cut potato (Solanum tuberosum) tubers resulted in the production of ortho-quinones whose function was to protect the tissue from bacterial infection at the site of the damage. They also postulated that PPO enzymes and their substrates are stored separated from each other ${ }^{3}$ and released and mixed only when the cell is mechanically damaged or infected by pathogens. This idea was later confirmed by the finding that PPO enzymes are located in the chloroplast, while their substrates are stored in the vacuole (Taranto et al., 2017).

Phenol (called for many years as carbolic acid) has been widely used as a disinfectant in hospitals in the $19^{\text {th }}$ century (Lister, 1875). Walker and Link (1935) investigated the in vitro antifungal efficacy of 21 phenol derivatives against four plant pathogenic fungi. From their results, they concluded that the mere presence a phenolic metabolite in a plant does not prove its role in the resistance against pathogens. In fact, depending on their concentration at the site of infection, phenolics may be entirely ineffective, or even have a stimulative effect on the pathogen.

Early findings on the roles of phenols in plant-pathogen interactions were reviewed by Gabor Farkas and Zoltan Kiraly (1962). Later research showed that plant phenolics may be metabolized to pro- and/or antioxidant derivatives, depending on the chemical structure of their parent compounds (Chobot and Hadacek, 2011).

\section{The phytoalexin theory}

Karl O. Muller played the key role in the development of the phytoalexin concept and also in the chemical and biological characterization of the first phytoalexin molecule. He worked at the Biological State Institute for Agriculture and Forestry in Berlin, Germany, and in 1940, together with Hermann Borger, proposed a detailed definition of phytoalexins as specific plant metabolites that are antimicrobial and are synthesized in the plant tissues following fungal or bacterial infection (Muller and Borger, 1940). They created the name phytoalexin from the Greek words phyto- (plant-related) and alexein (warding off). Most probably, Muller and Borger's discovery was strongly influenced by the Zeitgeist (the spirit of the age), because it happened in the dawn of the era of the "chemization" of agriculture: the time when synthetic organic chemicals were

${ }^{3}$ This could be one of the earliest examples of the possible involvement of cellular compartmentation in plant-pathogen interactions. introduced to control pests and diseases of crop plants (Komives, 2016).

After World War II, Muller moved to Australia, where he headed the CSIRO's Division of Plant Industry in Canberra for a number of years (Hoxtermann, 1991; Thomson, 2000). The first isolation of a phytoalexin (pisatin, Figure 1) in its pure chemical form (Cruickshank and Perrin, 1960) and the successful characterization of its chemical structure by Perrin and Bottomley (1961) took place in his laboratory. Pisatin was found to be produced in pea (Pisum sativum L.) in response to infection by the fungal pathogen Sclerotinia fructicola.<smiles>COc1ccc2c(c1)OC[C@@]1(O)c3cc4c(cc3O[C@H]21)OCO4</smiles>

Figure 1. The chemical structure of pisatin.

Following these findings, theoretical and applied research on phytoalexins intensified strongly. New chemical structures of different classes of phytoalexins in different plants were identified, and the routes and regulation of their biosynthesis were described (Ahuja et al., 2012). Although the published results were overwhelmingly supportive as regards the validity of the phytoalexin theory, several important questions were soon raised. For example, extensive research in the laboratory of Zoltan Kiraly at the Plant Protection Institute in Budapest, Hungary, showed that disease resistance of plants is influenced more by redox biochemical reactions (e.g., antioxidant capacity of plants) than the plants' ability to synthesize phytoalexins (Ersek et al., 1978; Ersek and Kiraly, 1986; Fodor et al., 1997). In addition, there is no explanation why phytoalexins are also synthesized in plants that are exposed to a wide range of unrelated abiotic stresses (heavy metals, herbicides, wounding, ethylene, etc., Komives and Casida, 1983).

Interestingly enough, in contrast to the extremely successful efforts to use tissues of plants and specific metabolites isolated from them as insecticides (Szekacs and Komives, 2017), no agents of plant origin have ever been introduced in practical use to control plant diseases in the field.

\section{CURRENT RESEARCH AND FUTURE PROSPECTS}

Regretfully, during last four decades, there have been no real scientific breakthroughs in the area of phytoalexin research - although the number of scientific papers published in the field has not been declining (Figure 2) and our knowledge has certainly increased. As compared to the second part of the 20th century, much less interest is directed today to the chemistry of phytoalexins, and only a few new antimicrobial phytochemicals were described recently (Jeandet et al., 2013). 
It is also worth noting, that the function of phytoalexins in the disease resistance of plants is quite restricted. Out of the 612 known plant families (The Plantlist, 2019), only a few dozen were identified as producers of phytoalexins (Echeverri et al., 2012). Furthermore, when leaves of 130 species of the Rosaceae family were investigated less than fifty showed the ability to synthesize antifungal compounds - and most of them were constitutive metabolites that were liberated from phenolics stored in the leaf tissue (Kokubun and Harborne, 1994).

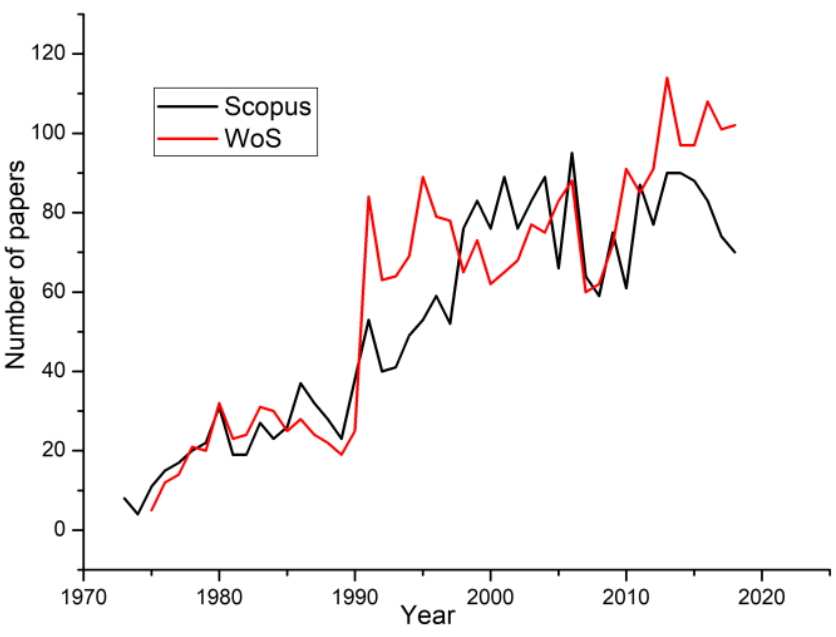

Figure 2. Yearly number of papers published with keywords including "phytoalexins" (data from Web of Science [WoS] and Scopus were retrieved on March 19, 2019).

Molecular biological techniques showed that plant-microbe interactions are highly complex processes, in which a number of receptors, promoters, transcription factors (and other proteins) play roles - in addition to small, specific metabolite molecules (Katagiri, 2018). Current, widely accepted thinking on plant resistance is based on the zigzag model of Jones and Dangl (2006) that defines successive stages of immunity and susceptibility mediated by interactions between a plant and its potential pathogen. Unfortunately, the roles phytoalexins may play in this model are not yet clearly defined.

\section{CONCLUDING REMARKS}

On a final note, we would like to comment on the broader biological functions of phytoalexins. Although these specific plant metabolites are non-specific regarding their toxicity to various pathogen races or species, they are synthesized in both non-specific and specific resistance events, and it is still unclear whether this phenomenon is the cause or a consequence of the resistance itself. Future research on phytoalexins should find the solution for this ambiguity. Recent studies by Bozso et al. (2016) showed the accumulation of phenolics in a non-specific resistance event (tobacco and Pseudomonas). Similar observations were published on specific resistance by others (cf. Kiraly at al., 2013).
Phytoalexins are known to be a significant part of the intricate system of plant-pathogen interactions. Nonetheless, we believe that their role in the resistance of plants against pathogen attack has been overestimated for many years. On another note, phytoalexins (and related specific metabolites) might be more important as ecochemicals (chemicals that mediate interactions between organisms, Hartmann, 2007) than currently assumed. In the future, major contributions to this area can be expected from

(1) metabolomics/chemotaxonomy studies on a wide range of families in the Plant Kingdom (this could include algae, as well),

(2) investigations of the biosynthesis of phytoalexins (regulation, pathways, storage, metabolism, etc.) in response to biotic (pests, pathogens, parasites, competitors, etc.) and abiotic stresses (pesticides, drought, mechanical injury, etc.), (3) on the possible roles of phytoalexins in interorganismal communications (in addition to direct toxicity), and (4) on the fate of phytoalexins in the ecosystem.

\section{ACKNOWLEDGMENTS}

We acknowledge with thanks the generous help by Professor Dr. Ekkehard Hoxtermann (Georg-August University, Gottingen, Germany) and Dr. Uwe Starfinger (Julius Kuhn Institute, Hannover, Germany) for providing us with valuable information on early phytoalexin-related discoveries and Dr. Balazs Barna, Dr. Zoltan Bozso, Dr. Gabor Gullner, Dr. Lorant Kiraly, as well as Dr. Agnes Szatmari (all from the Plant Protection Institute, ARC, HAS, Budapest, Hungary) for their constructive criticism.

\section{Public interest Statement}

This paper was written to critically evaluate the currently available information on the roles specific plant metabolites play in plant resistance against pathogens. We suggest that possible other function of these specific metabolites in environmental stress tolerance, such as cell wall reinforcing, intra- and interorganismal communications (not only with the pathogens), and ecological functions (during chemical stress and in competitive or symbiotic interactions), etc. need to be investigated. We conclude that the direct toxic action of phytoalexins against pathogens is probably less important than suggested in early studies. However, other roles they play may still be important in determining the outcome of plant-pathogen interactions.

\section{REFERENCES}

Ahuja, I., Kissen, R., Bones, A.M., 2012. Phytoalexins in defense against pathogens. Trends Plant Sci. 17, 73-90.

DOI: $10.1016 /$ j.tplants.2011.11.002

Bernard, N., 1911. Sur la fonction fongicide des bulbes d'ophrydees. Ann. Sci. Nat. Bot. Biol. 9, 221-234.

Bozso, Z., Ott, Peter G., Kaman-Toth, E., Bognar, G.F., Pogany, M., Szatmari, A., 2016. Overlapping yet response-specific transcriptome alterations characterize the nature of tobaccoPseudomonas syringae interactions. Front. Plant Sci. 7. 


\section{DOI: $\underline{10.3389 / f p l s .2016 .00251}$}

Candolle, A.P. de, Todd, R.B., London, K.C., Hospital, S.T., 1832 Physiologie végétale, ou, Exposition des forces et des fonctions vitales des végétaux pour servir de suite a l'organographie végétale, et d'introduction a la botanique géographique et agricole. Béchet jeune, Paris.

Candolle, A.P. de, 1804. Essai sur les propriétés médicales des plantes, comparées avec leurs formes extérieures et leur classification naturelle, par A.-P. Descandolle Méquignon aîné, Paris.

Carus, T.L., 1886. On the Nature of Things; trans. H.A.J. Munro. Georg Routledge \& Sons, London.

Chobot, V., Hadacek, F., 2011. Exploration of pro-oxidant and antioxidant activities of the flavonoid myricetin. Redox Rep. $16,242-247$.

DOI: $\underline{10.1179 / 1351000211 Y .0000000015}$

Cook, M.T., Bassett, H.P., Thompson, F., Taubenhaus, J.J., 1911. Protective enzymes. Science 33, 624-629.

DOI: $\underline{10.1126 / \text { science. } 33.851 .624}$

Cook, M.T., Wilson, G.W., 1915. The influence of the tannin content of the host plant on Endothia parasitica and related species. Bot. toth

DOI: $\underline{10.1086 / 331673}$

Cruickshank, I.A., Perrin, D.R., 1960. Isolation of a phytoalexin from Pisum sativum L. Nature 187, 799-800.

DOI: $\underline{10.1038 / 187799 \mathrm{~b} 0}$

de Bary, A., 1884. Vergleichende Morphologie und Biologie der Pilze, Mycetozoen und Bacterien. Engelmann, Leipzig.

Echeverri, F., Torres, F., Quiñones, W., Escobar, G., Archbold, R., 2012. Phenylphenalenone phytoalexins, will they be a new type of fungicide? Phytochem. Rev. 11, 1-12.

DOI: $\underline{10.1007 / \mathrm{s} 11101-010-9205-\mathrm{x}}$

Ersek, T., Kiraly, Z., 1986. Phytoalexins: warding-off compounds in plants? Physiol. Plant. 68, 343-346.

DOI: $\underline{10.1111 / \mathrm{j} .1399-3054.1986 . t b 01937 . x}$

Ersek, T., Kiraly, Z., Dobrovolszky, A., 1978. Lack of correlation between tissue necrosis and phytoalexin accumulation in tubers of potato cultivars. J. Food Saf. 1, 77-85.

DOI: $10.1111 / j .1745-4565.1977 . t b 00261 . x$

Farkas, G.L., Kiraly, Z., 1962. Role of phenolic compounds in the physiology of plant diseases and disease resistance. J. Phytopathol. 44, 105-150.

DOI: $\underline{10.1111 / \mathrm{j} .1439-0434.1962 . t b 02005 . \mathrm{x}}$

Focke, W.O., 1881. Schutzmittel der Pflanzen gegen niedere Pilze. Kosmos 5, 412-415.

Fodor, J., Gullner, G., Adam, A.L., Barna, B., Komives, T., Kiraly, Z., 1997. Local and systemic responses of antioxidants to tobacco mosaic virus infection and to salicylic acid in tobacco (role in systemic acquired resistance). Plant Physiol. 114, $1443-1451$.

DOI: $10.1104 / \mathrm{pp} .114 .4 .1443$
Gaumann, E., 1954. Toxins and plant diseases. Endeavour 13, 198 204.

Geng, X., Jin, L., Shimada, M., Kim, M.G., Mackey, D., 2014. The phytotoxin coronatine is a multifunctional component of the virulence armament of Pseudomonas syringae. Planta 240, $1149-1165$.

DOI: $10.1007 / \mathrm{s} 00425-014-2151-\mathrm{x}$

Hartmann, T., 2007. From waste products to ecochemicals: Fifty years research of plant secondary metabolism. Phytochemistry $68,2831-2846$.

DOI: $\underline{10.1016 / j . p h y t o c h e m .2007 .09 .017}$

Havens, J.N., 1792. Observations on the Hessian fly. Trans NY Soc. Agric. Arts Manuf. 1, 89-107.

Hogenhout, S.A., Van der Hoorn, R.A.L., Terauchi, R., Kamoun, S., 2009. Emerging concepts in effector biology of plantassociated organisms. Mol. Plant. Microbe Interact. 22, 115122.

DOI: $\underline{\text { 10.1094/MPMI-22-2-0115 }}$

Hoxtermann, E., 1991. Karl Otto Muller (1897-1978) und die Entdeckungsgeschichte der Phytoalexine. J. Phytopathol. 132, $161-167$.

DOI: $\underline{10.1111 / j .1439-0434.1991 . t b 00107 . x}$

Jeandet, P., 2015. Phytoalexins: current progress and future prospects. Molecules 20, 2770-2774.

DOI: $10.3390 /$ molecules 20022770

Jeandet, P., 2017. Structure, chemical analysis, biosynthesis, metabolism, molecular engineering, and biological functions of phytoalexins. Molecules 23, 61 .

DOI: $\underline{10.3390 / \text { molecules } 23010061}$

Jeandet, P., Clement, C., Courot, E., Cordelier, S., 2013. Modulation of phytoalexin biosynthesis in engineered plants for disease resistance. Int. J. Mol. Sci. 14, 14136-14170.

DOI: $\underline{10.3390 / i j m s 140714136}$

Jones, J.D.G., Dangl, J.L., 2006. The plant immune system. Nature 444, 323-329.

DOI: $\underline{10.1038 / \text { nature } 05286}$

Katagiri, F., 2018. Review: Plant immune signaling from a network perspective. Plant Sci. 276, 14-21.

DOI: $\underline{10.1016 / j . p l a n t s c i .2018 .07 .013}$

Kiraly, Z., Barna, B., Ersek, T., 1972. Hypersensitivity as a consequence, not the cause, of plant resistance to infection. Nature 239, 456-458.

DOI: $10.1038 / 239456 \mathrm{a} 0$

Kiraly, L., Kunstler, A., Bacso, R., Hafez, Y., Kiraly, Z., 2013. Similarities and differences in plant and animal immune systems - what is inhibiting pathogens? Acta Phytopathol. Entomol. Hung. 48, 187-205.

DOI: $10.1556 /$ APhyt.48.2013.2.1

Kokubun, T., Harborne, J.B., 1994. A survey of phytoalexin production in leaves of the Rosaceae by copper ions. Z. Für Naturforschung C 49, 628-634.

DOI: $10.1515 /$ znc-1994-9-1014 
Komives, T., 2017. Metabolomics - what nomenclature to use? Ecocycles 3, 1-3.

DOI: $\underline{10.19040 / \text { ecocycles.v3i2.78 }}$

Komives, T., 2016. Chemical plant protection. Past. Present. Future? Ecocycles 2, 1-2.

DOI: $\underline{10.19040 / \text { ecocycles.v2i1.47 }}$

Komives, T., Casida, J.E., 1983. Acifluorfen increases the leaf content of phytoalexins and stress metabolites in several crops. J. Agric. Food Chem. 31, 751-755.

DOI: $\underline{10.1021 / \mathrm{if} 00118 \mathrm{a} 018}$

Kuntze, O., 1877. Die Schutzmittel der Pflanzen gegen Thiere und Wetterungunst und die Frage vom salzfreien Urmeer, 1906th ed.

Lister, J., 1875. On recent improvemenets in the details of antiseptic surgery. The Lancet 105, 365-367.

DOI: $10.1016 / \mathrm{S} 0140-6736(02) 47104-8$

Mukhtar, M.S., McCormack, M.E., Argueso, C.T., PajerowskaMukhtar, K.M., 2016. Pathogen tactics to manipulate plant cell death. Curr. Biol. 26, R608-R619.

DOI: $\underline{10.1016 / \text { j.cub.2016.02.051 }}$

Muller, K.O., Borger, H., 1940. Experimentelle Untersuchungen uber die Phytophthora-Resistenz der Kartoffel. Zugleich ein Beitrag zum Problem der "erworbenen Resistenz" im Pflanzenreich. Arb. Biol. Reichsanst. Land- Forstwirtsch. 23, 189-231.

Perrin, D.R., Bottomley, W., 1961. Pisatin: an antifungal substance from Pisum sativum L. Nature 191, 76-77.

DOI: $\underline{10.1038 / 191076 \mathrm{a} 0}$

Petriacq, P., Stassen, J.H.M., Ton, J., 2016. Spore density determines infection strategy by the plant pathogenic fungus Plectosphaerella cucumerina. Plant Physiol. 170, 2325-2339.

DOI: $10.1104 / \mathrm{pp} .15 .00551$

Ross, A.F., 1961. Systemic acquired resistance induced by localized virus infections in plants. Virology 14, 340-358.

DOI: $10.1016 / 0042-6822(61) 90319-1$

Selosse, M.-A., Boullard, B., Richardson, D., 2011. Noel Bernard (1874-1911): orchids to symbiosis in a dozen years, one century ago. Symbiosis 54, 61-68.

DOI: $10.1007 / \mathrm{s} 13199-011-0131-5$

Silva, M.S., Arraes, F.B.M., Campos, M. de A., Grossi-de-Sa, M., Fernandez, D., Candido, E. de S., Cardoso, M.H., Franco, O.L., Grossi-de-Sa, M.F., 2018. Review: Potential biotechnological assets related to plant immunity modulation applicable in engineering disease-resistant crops. Plant Sci. Int. J. Exp. Plant Biol. 270, 72-84.

DOI: $10.1016 / j . p l a n t s c i .2018 .02 .013$

Snelders, N.C., Kettles, G.J., Rudd, J.J., Thomma, B.P.H.J., 2018. Plant pathogen effector proteins as manipulators of host microbiomes? Mol. Plant Pathol. 19, 257-259.

DOI: $\underline{10.1111 / \mathrm{mpp} .12628}$

Stakman, E.C., 1915. Relation between Puccinia graminis and plants highly resistant to its attack. J. Agric. Res. 4, 193-200.

Szatmari, A., Zvara, A., Moricz, A.M., Besenyei, E., Szabo, E., Ott, P.G., Puskas, L.G., Bozso, Z., 2016. Pattern triggered immunity (PTI) in tobacco: Isolation of activated genes suggests role of the phenylpropanoid pathway in inhibition of bacterial pathogens, PLoS ONE 9(8): e102869.

DOI: $10.1371 /$ journal.pone.0102869,2014

Szekacs, A., Komives, T., 2017. Research directions in plant protection chemistry. Ecocycles 3, 4-12.

DOI: $10.19040 /$ ecocycles.v3i2.71

Szent-Gyorgyi, A., Vietorisz, K., 1931. Bemerkungen uber die Funktion und Bedeutung der Polyphenol-oxydase der Kartoffeln. Biochem Z 233, 236-239.

Taranto, F., Pasqualone, A., Mangini, G., Tripodi, P., Miazzi, M., Pavan, S., Montemurro, C., 2017. Polyphenol oxidases in crops: biochemical, physiological and genetic aspects. Int. J. Mol. Sci. 18, 377.

DOI: $\underline{10.3390 / \mathrm{ijms} 18020377}$

The Plantlist, 2019.

http://www.theplantlist.org (accessed on March 17, 2019)

Thomson, A.D., 2000. Obituary: Ian Alfred Murray Cruickshank, 1924-2000. N. Z. J. Crop Hortic. Sci. 28, 293-300.

DOI: $\underline{10.1080 / 01140671.1997 .9514152}$

Walker, J.C., Link, K.P., 1935. Toxicity of phenolic compounds to certain onion bulb parasites. Bot. Gaz. 96, 468-484.

DOI: $\underline{10.1086 / 334495}$

Ward, H.M., 1902. On the relations between host and parasite in the bromes and their brown rust, Puccinia dispersa (Erikss.). Ann. Bot. 16, 233-316.

DOI: 10.1093 /oxfordjournals.aob.a088874

Ward, H.M., Cantab, S.D., Victoria, D.S., 1905. Recent researches on the parasitism of fungi. Ann. Bot. 19, 1-54.

DOI: 10.1093/oxfordjournals.aob.a088985 